UDC 347.51:376:343.8

DOI 10.32755/sjeducation.2020.01.153

Shportiuk O.,

Senior Lecturer of the Department of Pedagogy and Humanitarian Disciplines, Academy of the State Penitentiary Service, Chernihiv, Ukraine ORCID: 0000-0252-5594;

Shmelova R.,

Junior Researcher of the Department of Scientific Activities and International Cooperation, Academy of the State Penitentiary Service, Chernihiv, Ukraine

ORCID: 0000-0001-7227-5511

\title{
ORGANIZATION OF SPECIAL TRAINING OF PROBATION PERSONNEL FOR WORK WITH JUVENILES AS AN IMPLEMENTATION ELEMENT OF JUVENILE JUSTICE IN UKRAINE
}

The article considers the need to develop a state policy in the field of the rights protection of children who are in conflict with law in terms of providing children with special care and assistance by the state, given international obligations, constitutional requirements and the level of juvenile delinquency. The importance of juvenile justice implementation is substantiated as an effective social mechanism that allows to restore the physical, psychological and social status of juveniles who are in conflict with law.

We highlighted ans revealed the aspects of the juvenile justice implementation in the domestic legislation, the tasks facing future probation officers who will work with juveniles, defined by the requirements of international standards, domestic legislation and age characteristics of such category of probation clients. In order to achieve the probation goals, it is established that the staff must have not only legal knowledge, but also be able to professionally carry out social and educational work, implement effective social and educational technologies for juveniles, use new methods and programs to successfully correct social behavior of juveniles. new tools and techniques to determine the risks of crime.

In probation bodies, namely juvenile probation centers, should work personnel with appropriate knowledge and skills in relation to juveniles who have committed offenses, considering their age, socio-psychological, psychophysical and other features of their development. The main direction in the specialists training to work with juvenile offenders is the acquisition of competencies in social and educational work. It is been proved that the juvenile justice implementationas an element of state policy in the field of the rights protection of children who are in conflict with the law requires special training for social and educational work for future probation officers.

Key words: probation officers, professional training, juvenile justice, juveniles, social and educational work. 
Formulation of the problem. The reforms of European integration required a change in the course of state policy in the field of execution of criminal punishments in the direction of humanization of criminal law, especially for juveniles, improvement of the mechanism of their rights protection, compliance with international standards in the execution of punishments for this category of offenders. The creation of a specialized system to protect the child's rights has become a vital measure.

Analysis of the juvenile delinquency in Ukraine, as well as legislation that determines their legal status and courts ` powers, law enforcement bodies and the penitentiary system, opportunities for rehabilitation of juvenile offenders, gives grounds for an unequivocal conclusion about the need to create juvenile justice in Ukraine by reforming existing and introducing new institutions, also as involvement of non-governmental organizations.

However, the main guarantee of successful implementation of any reforms is the training of qualified personnel who will effectively perform new tasks and functions.

Analysis of the latest research and publications. Issues of protection of the rights and interests of juveniles who are in conflict with the law were studied by such domestic and foreign scholars as B. Ismailov, N. Krestovska, E. Melnykova, O. Protsyuk, V. Ternavska, L. Khasina, O. Yamkova and others. O. Galay, V. Dryzhak, O. Duka, V. Syniov, S. Chebonenko, I. Yakovets, O. Yanchuk thoroughly revealed the current state of study of various aspects of personnel training for penitentiary system and probation bodies. Socio-pedagogical ideas have become the subject of research of such famous scientists as L. Zavatska, A. Kapska, M. Lukashevych, N. Maksymova, I. Myhovych, V. Yahupov.

Purpose setting. Having considered the aspects of the implementation of juvenile justice in the domestic legislation, scientific approaches to training personnel for the State Penitentiary Service of Ukraine and the peculiarities of training specialists to work with juveniles who are in conflict with the law, need to justify the need to train specialists to work with juveniles in probation.

The main material. The issue of elements implementation of juvenile justice in Ukraine in recent years has become especially 
relevant as a means of ensuring fundamental rights and introducing a more progressive system of social rehabilitation of children who have come into conflict with the law. Analysis of foreign experience shows that the social rehabilitation of children who are in conflict with the law is an effective social mechanism that allows to restore the physical, psychological and social status of a child and to avoid tragic consequences.

Currently there is a tendency to reduce the number of juvenile convicts in prisons through the use of punishment and other methods of criminal law influence not related to isolation from society. However, the decrease in the number of juveniles in educational institutions of a closed type is not an indicator of a decrease in juvenile delinquency, as the quantitative indicators of juvenile delinquency are constant. According to the official data of the General Prosecutor's Office of Ukraine during 10 months in 2018, 3566 criminal proceedings involving juveniles were sent to court; during 10 months of 2019 - 3236 criminal proceedings were sent to court. The state and society place their hopes on the correction and social rehabilitation of juvenile offenders on probation bodies and juvenile probation centers [1].

The opening of juvenile probation centers can be considered as a significant step towards the establishment of juvenile justice. Today, there are 14 juvenile probation centers within the structure of the Probation Center of the Ministry of Justice of Ukraine, where according to the law, probation measures are applied to persons aged 14 to 18, considering the age and psychological characteristics of juveniles. According to official data, as of March 1, 2019, 1,004 juveniles were registered with the authorized bodies for probation: 970 - released from serving a probation sentence; 34 - convicted to public works (including administrative penalties) [2].

In order to properly fulfill Ukraine's international obligations in providing children with special care and assistance from the state, implementation of the Constitution of Ukraine, as well as from the point of the level of juvenile delinquency, there is a need to develop state policy to protect children's rights who are in conflict with the law. There is a need to implement juvenile justice in Ukraine, as a way of organizing the legal system, which creates a system of 
bodies, institutions and organizations that administer justice in cases of offenses committed by juveniles.

Looking back in the history of the implementation of elements of juvenile justice in Ukraine, considering the fact that more than 100 years of experience in the emergence and development of juvenile justice in Europe and America, in 2011 Ukraine adopted the "Concept for the Development of Juvenile Justice" (hereinafter - the Concept) and approved an Action Plan for its implementation. This Concept is based on restorative, rehabilitation, and protective justice, which should promote the social adaptation and integration of juvenile offenders, and in the Action Plan for the implementation of the Concept, the first module is a personnel module (training of specialists in juvenile justice). Such specialists include juvenile judges; juvenile prosecutors; juvenile lawyers; juvenile police officers, investigators, social workers; probation officers for work with juveniles; employees of the penitentiary system for work with juveniles in closed educational institutions; coordinators and leaders of restorative justice programs; psychologists, psychiatrists, medical professionals who will work directly with juvenile offenders; educators, teachers who are in schools (colleges) of social rehabilitation. The Strategy for the Reform of the Judiciary and Related Legal Institutions for 2015-2020 (hereinafter - the Strategy) in sub-paragraph 5.11 indicates the need to "retrain and train penitentiary personnel to create a full-fledged modern probation service; providing technical base for the functioning of the probation service" [4].

In fact, the first real step towards the establishment of juvenile justice in Ukraine was the adoption in 2012 of the Criminal Procedure Code of Ukraine, which contained a separate chapter №38 "Criminal proceedings against juveniles", which regulates criminal proceedings against juveniles, considering their age, intellectual, psychological and other features, lack of life experience, a certain limitation of general civil capacity and liability, etc. In addition, this chapter provides additional guarantees of the truth, protection of the rights and legitimate interests of juveniles, the preventive effect of justice. 
In order to implement an inter-institutional platform for systematic discussion and resolution of juvenile justice issues, making agreed decisions that meet the interests of a child, the Cabinet of Ministers of Ukraine establishes a temporary advisory body in 2017- the Interdepartmental Coordination Council for Juvenile Justice [5].

In 2018, the concept of the Law "On Justice for Children" was approved and later presented its draft, which, according to the authors, should create conditions for the organization and effective functioning of the justice system for children and become a legal basis for crime prevention in the environment, justice for children who are in conflict with the law, considering the age peculiarities of their development, social rehabilitation of children who are in conflict with the law and bring domestic juvenile justice as close as possible to international standards.

In order to introduce effective mechanisms in the justice system for juveniles, aimed at strengthening the responsibility of the state and society for their development, increasing the level of social and legal protection, reducing crime, as well as correction and social rehabilitation of juveniles who are in conflict with the law, by the Order of Cabinet of Ministers approved the National Strategy for Reforming the Justice System for Children by 2023 dated December 18, 2018 № 1027-p[7], and on November 27, 2019 approved the Action Plan for the implementation of the National Strategy, which states:

- improvement of the system of training, advanced training of specialists involved in the implementation of prevention and correction programs, monitoring of their effectiveness, assessment of the risks of committing offenses by children;

- ensuring the judges specialization of dealing with administrative offenses involving juvenile sand other professionals of the justice system for children (prosecutors, lawyers, social workers, teachers, psychologists, police officers, probation authorities, etc.) considering the requirements of international standards in the training relevant specialists;

- increasing the professional potential of employees of the social and psychological service of penitentiary institutions, probation 
bodies to ensure the resocialization of juvenile convicts by developing and implementing appropriate training programs [8].

An important aspect in the process of reforming justice for children, namely in the implementation of juvenile justice, as we can see, is the training of personnel to work with juveniles who are in conflict with the law.

Conclusions. The professional activity of future juvenile probation officers aims to ensure the implementation of state policy in the field of juvenile justice through the implementation of its tasks and functions, as well as contributes to public safety by correcting juvenile convicts. However, considering the age and psychological characteristics of juveniles who are in conflict with the law, probation bodies (juvenile probation centers) should have personnel with appropriate knowledge and skills to work with this category of offenders. Considering juveniles' age, socio-psychological, psychophysical and other features of their development belong to the vulnerable category of citizens, and therefore require a special approach in criminal proceedings, sentencing and execution, as well as in conducting social and educational activities with them.

Accordingly, probation officers should establish an effective system for the rehabilitation of juvenile offenders in order to rehabilitate and re-socialize them. The main direction in the training of specialists to work with juvenile offenders is the acquisition of competencies in social and educational work. Today, the ideas of social and educational work and social rehabilitation reflect the purpose of punishing juvenile offenders.

Thus, the implementation of juvenile justice as an element of state policy in the field of protection of the rights of children in conflict with the law requires special training for social and educational work for future probation officers.

\section{References}

1. Unified Report on Criminal Statistics: Criminal offenses by state Statistical information of the Prosecutor General's Office of Ukraine, available at: https://old.gp.gov.ua/ua/stst2011.html?dir_id=113898\&libid= 100820\&c $=$ edit\&_c=fo\# (last accessed 14.05.2020). 
2. Certificateon the Number of Juveniles Registered with the Authorized Bodies of Probation, available at: http://www.probation.gov.ua/? page_id=153 (last accessed14.05.2020).

3. Ukraine (2011), On the Plan Approval of the Measures on Implementation of the Concept of Development of Criminal Justice Concerning Juveniles in Ukraine: Law of Ukraine, Cabinet of Ministers of Ukraine dated October 12, 2011 № 1039-p., available at: https://zakon.rada.gov.ua/laws/show/1039-2011-\%D1\%80 (lastaccessed14.05.2020).

4. Ukraine (2015), Strategy for Reforming the Judiciary and Related Legal Institutions for 2015-2020: Approved by the Decree of the President of Ukraine dated May 20, 2015 № 276/2015, available at: http://zakon2.rada.gov.ua/laws/show/276/2015 (last accessed25.03.2018).

5. Ukraine (2017), On the Establishment of the Interdepartmental Coordination Council for Juvenile Justice: Resolution of the Cabinet of Ministers of Ukraine dated May 24, 2017 № 357, available at: https://zakon.rada.gov.ua/laws/show/357-2017-\%D0\%BF (last accessed 14.05.2020).

6. Ukraine (2018), On approval of the National Strategy for Reforming the Justice System for Children by 2023 dated December 18, 2018 № 1027-p., available at: https://zakon.rada.gov.ua/laws/show/1027-2018-\%D1\%80.

7. Ukraine (2019), On approval of the Action Plan for the Implementation of the National Strategy for Reforming the Justice System for Children by 2023: Order of the Cabinet of Ministers of Ukraine dated November 27, 2019 № 1335-p., available at: https://www.kmu.gov.ua/npas/pro-zatverdzhennya-planu-zahodiv-z-a1335r (last accessed14.05.2020).

8. Ukraine (2015), „On Probation”, Verkhovna Rada of Ukraine dated Fabruary 05, № 160-VIII, № 13, Art. 93.

\section{Шпортюк О. М., Шмельова Р. I., ОРГАНІЗАЦІЯ СПЕЦАЛЬНОЇ ПІДГОТОВКИ ПЕРСОНАЛУ ПРОБАЦІЇ ДЛЯ РОБОТИ З НЕПОВНОЛІТНІМИ ЯК ЕЛЕМЕНТ ВПРОВАДЖЕННЯ ЮВЕНАЛЬНОЇ ЮСТИЦІЇ В УКРАЇНІ}

У статті аргументовано необхідність розроблення державної політики у сфері захисту прав дітей, які потрапили в конфлікт із законом у частині забезпечення дітям особливого піклування та допомоги з боку держави, з огляду на міжнародні зобов'язання, вимоги Конституиії та рівень дитячої злочинності. Обтрунтовано важливість впровадження ювенальної юстищії як ефективного сочіального механізму, щзо дає змогу відновити фізичний, психологічний та сочіальний статус неповнолітніх, які потрапили в конфлікт із законом. 
Висвітлено аспекти впровадження ювенальної юстиції у вітчизняному законодавчому просторі, розкрито завдання, щзо стоять перед майбутніми офіцерами органу пробації, які працюватимуть з неповнолітніми, щуо визначені вимогами міжнародних стандартів, вітчизняного законодавства та віковими особливостями ичєї категорії клієнтів пробації. Встановлено, щзо для досягнення цілей пробації персонал повинен володіти не лиме трунтовними юридичними знаннями, а вміти професійно здійснювати саме соціальновиховну роботу, впроваджувати ефективні сочіально-виховні технології щуодо неповнолітніх, використовувати нові методики та програми з метою успішної корекції сочуіальної поведінки неповнолітнього злочиния, застосовувати нові інструменти та методики з метою визначення ризиків скоєння злочинів.

У статті зазначено, щзо в органах пробації, а саме в центрах ювенальної пробації повинен працювати персонал, який володіє відповідними знаннями та навиками роботи щзодо неповнолітніх, які вчинили правопорушення, з урахуванням вікових, сочіально-психологічних, психофізичних та інших особливостей їх розвитку. Основним напрямком у підготовці фахівців для роботи з неповнолітніми порушниками закону є набуття компетентностей з соціальновиховної роботи. У статті встановлено, шо впровадження ювенальної юстиції як елементу державної політики у сфері захисту прав дітей, які потрапили в конфлікт із законом, вимагає забезпечення спеціальної підготовки до соцііально-виховної роботи для майбутніх офіuерів органу пробації.

Ключові слова: офічери органу пробачії, професійна підготовка, ювенальна юстиція, неповнолітні, сочіально-виховна робота.

\section{Список використаних джерел}

1. Сдиний звіт про кримінальні правопорушення по державі: статистична інформація Генеральної прокуратури України. URL: https://old.gp.gov.ua/ua/stst2011.html?dir_id=113898\&libid=100820\&c=ed it\&_c=fo\# (дата звернення 14.05.2020).

2. Довідка про чисельність неповнолітніх осіб, які знаходяться на обліку уповноважених органів 3 питань пробації. URL: http://www.probation.gov.ua/?page_id=153 (дата звернення 14.05.2020).

3. Про затвердження плану заходів щодо реалізації Концепції розвитку кримінальної юстиції щодо неповнолітніх в Україні: розпорядження від 12 жовтня 2011 р. № 1039-р. / Кабінет Міністрів України. URL: https://zakon.rada.gov.ua/laws/show/1039-2011-\%D1\%80 (дата звернення 14.05.2020).

4. Стратегія реформування судоустрою, судочинства та суміжних правових інститутів на 2015-2020 роки: затв. Указом Президента України від 20.05.2015 p. № 276/2015. URL: http://zakon2.rada.gov.ua/laws/show/276/2015 (дата звернення 25.03.2018).

5. Про утворення Міжвідомчої координаційної ради з питань правосуддя щодо неповнолітніх: постанова Кабінету Міністрів від 24 тра- 
вня 2017 р. № 357. URL: https://zakon.rada.gov.ua/laws/show/357-2017$\% \mathrm{D} 0 \% \mathrm{BF}$ (дата звернення 14.05.2020).

6. Про схвалення Національної стратегії реформування системи юстиції щодо дітей на період до 2023 року від 18 грудня 2018 р. № 1027-p. URL: https://zakon.rada.gov.ua/laws/show/1027-2018-\%D1\%80.

7. Про затвердження плану заходів з реалізації Національної стратегії реформування системи юстиції щодо дітей на період до 2023 року: розпорядження Кабінету Міністрів України від 27 листопада 2019 р. № 1335-p. URL: https://www.kmu.gov.ua/npas/pro-zatverdzhennya-planuzahodiv-z-a1335r (дата звернення 14.05.2020).

8. Про Пробацію: Закон України від 05.02.2015 р. № 160-VIII. Biдомості Верховної Ради України. 2015. № 13. Ст. 93. 